representative, and I regret to be obliged to again state that there is no satisfactory evidence to show that Professor Lustig's serum can reduce the mortality-rate in the slightest degree. The remainder of Dr. Choksy's letter is wholly irrelevant to the point at issue.

$$
\text { I am, Sirs, yours faithfully, }
$$

July 25th, 1899.

$$
\text { Your SPECTaL Correspondent. }
$$

\section{THE USE OF BROMIDE OF STRONTIUM IN EPILEPSY.}

To the Eators of THE LANCET.

SIRs, - I have read with much interest Dr. J. G. Smith's report ${ }^{i}$ on the use of bromide of strontium in 12 cases of epileptic insanity compared with that of the bromide of potassium in the same cases. As I have used the strontium salt for some years in a considerable number of cases of epilepsy with marked success, perhaps I may be permitted to make a few remarks upon Dr. Smith's conclusions. I am sure he will agree with me that 12 cases are far too few to base any reliable conclusions upon, but accepting the data for what they are worth, his results may be summarised as follows: (1) That the fits under the strontium were somewhat less frequent and of a milder type and the rash was much less marked; and ( 2 ) that the potassium salt required a smaller dose, the effect seemed to be more rapid and more lasting, judged only, however, by the necessity of increasing the dose of the strontium. So that in these series of cases the attacks were less, and milder, under the strontium.

Surely, therefore, his ultimate conclusion "that the bromide of potassium must be regarded as the more generally useful drug in the treatment of epilepsy," is not warranted by his facts. There is, however, one more important advantage that the strontium salt has over the potassium that Dr. Smith has not referred to-viz., the strontium salt does not produce that marked depression which the potassium does so frequently when taken for some time. In a medicine that has to be continued for years this is a most important point. I have met with more than one case of epilepsy where the patients have assured me that they would rather have the fits than suffer from the depression which is produced by the bromide of potassium. My own experience of the strontium salt as compared with the potassium is distinctly in favour of the former. Most of my patients had previously been treated with the potassium and certainly in diminishing the number of attacks and in no small number preventing their recurrence, in the absence of depression, the strontium salt has given me remarkably successful results.

I hope Dr. Smith will continue his interesting investigation.

I am, Sirs, yours faithfully, NTONY Roche, M R C.P. Irel.

Dublin, August 34th, 1899. Professor, Catholic University, \&c.

\section{HOSPITAL ABUSE.}

\section{To the Editors of THE LANCET.}

SIRs,-The following case may be worthy of reporting for the double purpose of warning my brethren in the country and of cau'ioning the London hospitals. An operation had been arranged for the removal of adenoids and nasal spur from a girl in a village near here. No question was raised about fee and final arrangements were being made when I received a note from the mother saying that after seeing me on the previous day her husband on coming home told her that they would pass their holiday in London and that he would then take his child to Dr. Mackenzie's hospital. I am aware, as all who have practised in London must be, how extremely difficult it is to check abuses, but is the honest attempt made always? At the general hospitals it is said to be done, yet $I$ have heard of patients who were unable to pay the operation fee of London consultants being admitted by them to the hospitals to which they belonged and the operation being performed for nothing. At some of the special hospitals abuses are checked or the effort to do so is made, but this is not always the case. The obvious and only argument which general practitioners have is to practise the specialties themselves and so not to give the opportunity for going to the large towns. A general anæsthetic is rarely necessary in throat work.

I am, Sirs, yours faithfully,

GRIFFITH C. WILKIN,

Late Surgeon to the London Throat Hospital.

West Coker, near Yeovil, Somerset, August 11th, 1899.

\section{THE FINANCES OF THE IRISH BRANCH MEDICAL COUNCIL.}

To the Editors of THE LANCET.

SIRs,-.-My attention has only now been directed to THE LANCET of June 24th in which your "Own Correspondent" says, under the heading of the "Finances of the Irish Branch Council": "It would appear that the assets of the Irish Branch Council have dropped from $\$ 801$ 18s. $5 d$. in 1896 to $£ 2849$ s. 10d. in 1898, and it was only natural that the Irish representatives (all of whom reside in Dublin) should be asked by the President to explain how in two years there should be such an extraordinary drop in their receipts of £517." Kindly allow me to state that the income of the Branch for registrations for the year ending Dec. 31st, 1896, was $£ 6732 s .6 d$. and that for the year ending Dec. 31st, 1898, was £691 15s.

I am, Sirs, yours faithfully,

Dublin, August 14th, 1899

S. WESLEY WILSON, Registrar.

\section{“'TUBERCULAR' AND 'TUBERCULOUS.'”}

\section{To the Editors of THE LANOET.}

SIRS, - In answer to the letter of "F.R.O.S." in THE LANCET of August 12th kindly allow me to amplify the objections to the use of the expression "tuberculous disease." The suffix " ous" means " full of," "abounding in"; "ar" means " pertaining to," "having the character or quality of." The letter " $\mathrm{T}$ " has not yet been reached in the Oxford English Dictionary, but Dr. J. A. H. Murray kindly wrote to a friend concerning the words: "I think it is correct to use both tubercular and tuberculous, according to the sense; the two words differ as do popular-of, pertaining to, of the nature of the people; populous-abounding in people." "The analogy of popular and populous ought to keep you right, or that of any of the numerous pairs in -al, -ous, as, in sooth, numeral, numerons. As you know, $-a l$ and -art are the same suffix." "Attention, therefore, to any pair in -al, -ous, will also show how to discriminate tuberoular, tuberculous."

According to the principle thus laid down by Dr. Murray "tuberculous disease" is as meaningless as "populous fallacy." Granular, granulous ; nebular, nebulous ; nodular, nodulous ; tubular, tubulous-occur at once to the mind as further instances of the distinction. The report of the Royal Commission on Tuberculosis was issued in 1898, and in it "tubercular" is invariably used to qualify disease, "tuberculous" to qualify animals or carcases. The last edition of the "Nomenclature of Diseases," which sanctions only "tubercular," was published by the Royal College of Phy. sicians of London in 1896. We may therefore infer that accurate writers still observe the distinction between the two words. If the proposal (which is not mine) be adopted, that the terms "tubercle," "tubercular," and "tuberculous" be restricted to the products of Koch's bacillus, then of course "tubercular leprosy" will have to be dropped. "Nodular leprosy," an expression already in use, will in that case probably replace "tubercular or tuberculated leprosy." Therefore, touching the supposition that if I am right " tubercular" leprosy must be a product of the tubercle bacillus," I might "deny the allegation and defy the alligator."

I am, Sirs, yours faithfully, Wililiam R. HugGard.

Davos Platz, Switzerland, August 13th, 1899

\section{To the Elditors of THW LANGET.}

SIRS,-Dr. W. R. Huggard's deference to literary precedents is little short of pedantic. The chief requisite in scientific language is precísion combined with conciseness, but Dr. Huggard refuses to avail himself freely of the convenient word "tuberculous" and prefers to make "tuber. cular" serve the double purpose of denoting without further qualification not only nodular formation of any kind but 